\title{
THE INTERNATIONAL CONGRESS OF TOXINOLOGY IN BRAZIL: A BRIEF OVERVIEW
}

\section{De Lima ME (1), Fortes-Dias CL (2)}

(1) Laboratory of Venoms and Animal Toxins, Department of Biochemistry and Immunology, Institute of Biological Sciences, Federal University of Minas Gerais, Belo Horizonte, Minas Gerais State, Brazil, and President of the Brazilian Society of Toxinology; (2) Laboratory of Molecular Biology and Bioinformatics, Center for Research and Development, Ezequiel Dias Foundation, Belo Horizonte, Minas Gerais State, Brazil, and Vice President of the Brazilian Society of Toxinology.

For the first time in almost 50 years, Brazil had the opportunity to hold a congress of the International Society on Toxinology (XVI World Congress of the IST), together with the $10^{\text {th }}$ Congress of the Brazilian Society of Toxinology - SBTX. The event was held at the Eco Resort do Cabo de Santo Agostinho, in the state of Pernambuco, on March 15 to 20, 2009. At the congress, about 550 participants from 45 countries on five continents presented the results of 480 studies on toxins. The theme of the meeting was "Biodiversity in Toxins: Tools for Biological Research and Drug Development" and focused on plain and sectorial conferences, symposia, oral presentations and poster sessions. The enthusiastic participation of senior and young scientists as well as the massive presence of students (about 200 registrations) were highly remarkable.

The opening session was preceded by the presentation of a folkloric ballet, a magnificent exhibition of the rich regional music and dance traditions, in a typical Brazilian welcome. After a few words from the presidents of the Scientific Committee (Dr. Célia Regina Carlini), the International Society on Toxinology (Dr. Ponnanpalam Gopalakrishnakone), the Brazilian Society of Toxinology (Dr. Maria Elena de Lima), the Coordination for the Improvement of Higher Education Personnel - CAPES (Dr. Jorge A. Guimarães), as well as from a local authority (representing the Secretary of Health of Cabo de Santo Agostinho), the scientific activities began with a lecture by 
Dr. Peter Roepstorff (University of Southern Denmark), on mass spectrometry, a powerful technique largely employed in protein studies in different fields of science, including Toxinology. After that, all the participants were invited for dinner.

This exciting congress included presentations and fruitful discussions on toxins from different organisms such as bacteria, fungi, arthropods, fishes, reptiles, frogs, algae, snails, plants, among others. The best posters, selected by an international committee of senior scientists, were recognized with awards and honorable mentions, as follows: three prizes offered by IST, three by SBTx (in honor of the late Professor Carlos Ribeiro Diniz), one by Venom Supplies Pty Ltd. and one by the Toxinomics Foundation called the André Menéz Prize.

Dr. Cesare Montecucco, from the Padova University (Italy), was granted the Redi Award that is traditionally offered by IST in their triannual meetings to a distinguished scientist in Toxinology. Dr. Montecucco has dedicated many years of his scientific life to studying the action mechanisms of microbe and snake toxins.

The beautiful natural scenery, the pleasant weather and the passion for toxins made a perfect combination for bringing people together in an intensive and motivated interaction. The success of this meeting was acknowledged by many participants who subsequently sent us congratulatory emails for its high scientific level and overall organization.

We would like to take this opportunity to thank many members of SBTx who worked hard to make this event possible, as well as IST members that also collaborated with us. We are indebted to several Brazilian funding agencies, the National Council for Scientific and Technological Development - CNPq, CAPES, state agencies (FAPs), other Brazilian public scientific foundations (Oswaldo Cruz Foundation, Butantan Institute, Ezequiel Dias Foundation) and all other sponsors for their financial support.

\section{CORRESPONDENCE TO:}

MARIA ELENA DE LIMA, Laboratório de Venenos e Toxinas Animais, Departamento de Bioquímica e Imunologia, Instituto de Ciências Biológicas, Universidade Federal de Minas Gerais, Av. Antônio Carlos, 6627, Belo Horizonte, MG, 30171-970, Brasil. Phone: +55 313409 2659. Fax: +55 313409 2614. Email: delima@icb.ufmg.br 